\title{
A case study approach for developing supply chain management models
}

\author{
A. K. M. Nurol Huda ${ }^{1}$, Bishwajit Banik Pathik ${ }^{2}$, Ashfaque A. Mohib ${ }^{3}$, Md. Mamun Habib ${ }^{4}$ \\ ${ }^{1}$ Supply Chain Department, JMI Group, Dhaka, Bangladesh \\ ${ }^{2}$ Department of Electrical and Electronic Engineering, American International University-Bangladesh, Dhaka, Bangladesh \\ ${ }^{3}$ Department of Operations Management, American International University-Bangladesh, Dhaka, Bangladesh \\ ${ }^{4}$ School of Quantitative Sciences (SQS), Universiti Utara Malaysia (UUM), Kedah, Malaysia

\section{Email address:} \\ huda3217@yahoo.com (A. K. M. N. Huda), bishwajit.b.pathik@gmail.com (B. B. Pathik), mohib@aiub.edu (A. A. Mohib), \\ md.mamun@uum.edu.my (M. M. Habib)
}

\section{To cite this article:}

A. K. M. Nurol Huda, Bishwajit Banik Pathik, Ashfaque A. Mohib, Md. Mamun Habib. A Case Study Approach for Developing Supply Chain Management Models. International Journal of Business and Economics Research. Special Issue: Supply Chain Management: Its Theory and Applications. Vol. 3, No. 6-1, 2014, pp. 6-14. doi: 10.11648/j.ijber.s.2014030601.12

\begin{abstract}
This descriptive analysis exemplifies various events in sequence to design conceptual Supply Chain Management (SCM) model for JMI Group in order to explain different functions under SCM department. JMI Group, one of the prominent and diversified universal corporations in Bangladesh, was established in April 1999 and comprised of 12 subsidiary enterprises covering both manufacturing and service industries. Its SCM organization is framed based on primary data, i.e. interviewing top management, other stakeholders and secondary data like official documents, internal reports, websites, books, journals, conferences, etc. This paper develops conceptual structure for JMI group, principally a holistic view, simplified models for individual company and integrated models signifying manufacturing process and service process. The individual models exemplify distinct supply chain management for all the subsidiary companies. Each framework methodically establishes suppliers in terms of internal and external, process through the manufacturing and service industries, customers, i.e. internal and external, and finally the end users. The integrated models illustrate that the subsidiary companies of JMI Group are interlinked with each other through complex networks in terms of either internal supplier or internal customer either as manufacturing or service industry. These suggested models would be appropriate towards all other group of companies in developing countries those intend to put into practice modern supply chain management perception into the business. This case study would expose the additional frontiers for potential researchers as well as practitioners to pursue research on SCM for the conglomerates locally and internationally as well as to implement model for real life application respectively.
\end{abstract}

Keywords: Supply Chain Management, SCM, JMI Group, Manufacturing Industry, Service Industry, Model

\section{Introduction}

Supply Chain comprises all parties related to satisfying customer demand directly or indirectly [1]. Raw materials and finished products, Suppliers and customers, and flow of goods (services), information and funds are the three entities of basic supply chain. Manufacturing and service industries have different basic supply chains as these contain supplier, manufacturer, distributor, retailer, customer and supplier, service provider, customer, consumer respectively. Goods/ service, information and fund flow in both directions in both the circumstances where all the above steps may not exist. The management of flows between and among supply chain phases to increase overall supply chain profitability is defined as supply chain management (SCM) $[2,3]$.

JMI Group is one of the encouraging and fast growing companies in Bangladesh. JMI Bangla Company Ltd (later it was renamed as JMI Syringes \& Medical Devices Limited) was founded in 1999 as the first concern of this Group. The Group is now expanded to twelve companies having direct investment of BDT 10 billion from Japan and South Korea. Saving lives by manufacturing state-of-the-art and inventive produces and work for the benefit of the humanity are the commitments of this Group.

This essay designs conceptual structure of SCM for JMI group, principally a holistic view, simplified models for 
particular company and integrated models for manufacturing and service process of the whole Group. The individual models demonstrate distinctive supply chain management for all the subsidiary concerns. Suppliers in terms of internal and external, process through the manufacturing and service industries, customers i.e. internal and external, and finally the end users are revealed methodically in every framework. The integrated models show how the supply chains (manufacturing and service process) of all the subsidiary companies of JMI Group are interlinked with each other by performing either as internal supplier or internal customer.

Literature Review, Methodology, SCM at JMI Group and conclusion are elaborated chronologically in the subsequent features of this article.

\section{Literature Review}

Supply chain is defined as an arrangement of enterprises that are engaged, through upstream and downstream links, in the numerous methods and actions that generate value in the form of products and services in the hands of the final customer [4]. Fig. 1 shows an example of a basic supply chain for manufacturing industry.

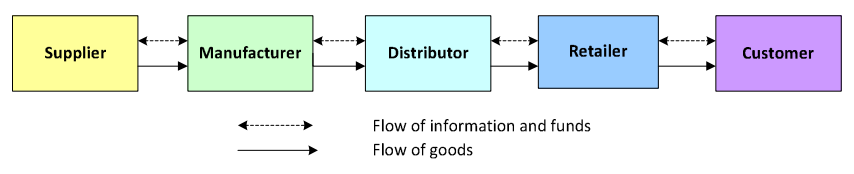

Figure 1. The Basic Supply Chain of manufacturing industry [1]

An example of a basic supply chain for service industry is shown in Fig. 2.

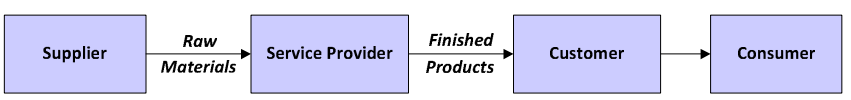

Figure 2. The Basic Supply Chain of service industry

Suppliers, manufacturers, distributors, retailers, customers and suppliers, service providers, customers, consumers respectively are contained in the supply chain of manufacturing and service industries. The customers are the hub of the chain as the key purpose of the existence of any supply chain is to fulfill customer necessities. It is creating profit for itself through the process [1].

The supply chain is considered as a single process. Liability for the various sections in the chain is not split and shifted to operational areas such as manufacturing, purchasing, distribution, and sales. SCM demands for, and in the end rest on, strategic decision-making. "Supply" is a common goal of almost every role in the chain and is of specific strategic significance because of its influence on allinclusive costs, profits and market share. SCM calls for dissimilar point of view on inventories that are used as a balancing tool of last, not first, option. A latest method to systems is essential - integration rather than interfacing [5].

Key economic benefits are brought by SCM to businesses as diverse as manufacturing, retail, and service organizations, etc. [6]. Re-cycling was included in the expanded scope of SCM [7]. Entire movement of materials from suppliers through end users is dealt with by SCM [8]. It highlights "total" incorporation of all members within the supply chain, a realistic methodology is to ponder only strategic suppliers and customers since maximum supply chains are too difficult to achieve full integration of all the supply chain components [9].

SCM is necessary for several causes: refining operations, superior outsourcing, growing profits, increasing customer contentment, creating quality products, deal with competitive stresses, growing globalization, growing importance of Ecommerce, and rising complexity of supply chains [10]. It is relatively easy to define the supply chain of manufacturing industry. In this context each participant in the chain receives inputs from a set of suppliers, processes those inputs, and delivers them to a different set of customers [11]. Business organization is assisted by SCM to contest in the dynamic international market. Integrating activities across and within organizations for providing the customer value is the objective of SCM.

\subsection{Definitions of SCM}

Supply chain is well-defined as all the events engaged in delivering a product from raw materials to the customer. It includes sourcing raw materials and parts, manufacturing and assembly, warehousing and inventory tracking, order entry and order management, distribution across all channels, delivery to the customer, and the information systems needed to monitor all of these accomplishments. SCM synchronizes and incorporates all of these activities into an unbroken activity. It associates all of the participants in the chain including sections within an establishment and the external partners including suppliers, carriers, third party companies, and information systems providers [12].

Several writers defined SCM in operational terms encompassing the flow of materials and products, some observed it as a management philosophy, and some observed it in terms of a management process [13], some observed it as combined system. Writers have even hypothesized SCM differently inside the same article: as a management philosophy on the one hand, and as a form of combined system amongst vertical integration and distinct characteristics on the other hand [14].

SCM was primarily associated to the inventory management in a supply chain. This idea was later stretched to include management of all works inside a supply chain. "SCM involves the management of flows between and among phases in a supply chain to minimize total cost" according to Chopra and Meindl [1]. This meaning denotes that SCM encompasses managing of flows of products, information, and finance upstream and downstream in the supply chain. In the progress of time, the most significant paybacks to businesses with advanced SCM capabilities will be drastically enhanced customer responsiveness, developed customer service and satisfaction, better flexibility for changing market conditions, enhanced customer retention 
and more effective marketing [6].

SCM is a perception, "whose prime objective is to incorporate and accomplish the sourcing, flow, and control of materials using a total systems outlook through multiple tasks and multiple stages of suppliers" [15]. Stevens [16] described the objective of SCM was to orchestrate the customers' requirements with materials flow to attain a balance among contradictory goals of maximum customer service, minimum inventory management, and low unit costs.

Integrated SCM is about going from the external customer and then management of all the methods that are required to deliver the customer with value in a horizontal way [17]. Usually, SCM encompasses integrated tasks from raw materials to end products. It also comprises integrated management of each business all over the entire chain $[6,18]$. The integrated methods necessary for managing goods from the preliminary source of supply to point of consumption can be demonstrated through the examination of SCM for manufacturing. It also contains wide-ranging events that material and service suppliers, manufacturers, wholesalers, and retailers have executed for years. Every supply chain members manage to improve performance of their own businesses. Very little concentration is provided to the benefits of managing the whole supply chain procedure on an integrated basis [19].

First, there are meanings characterized by the simplest thoughts of SCM, one is "the capacity to get nearer to the consumer" [20]. Another is that the supply chain is the movement of information and material from suppliers to customers [21]. A concern's supply chain, internal or external, is a resource to be exploited for improved market status and boosted competitive gain. Strategic use of this resource necessitates that concerns do the subsequent [17]:

1 Achieve a closer insight of their customer' and future customers' requirements, both nationally and internationally;

2 Recognize their suppliers' core capabilities in fulfilling customer needs;

3 Decide where redundancies and incompetence lie inside the supply chain in relation to recent and future competitive necessities;

4 Foster relationships and alliances with suppliers who have significant competencies that reinforce, supplement, and improve internal core competencies nationally and internationally.

\section{Methodology}

The analysis of this research is based on secondary data, including online databases, digital libraries, books, journals, conference papers, etc. Wide-ranging SCM research papers of academicians and practitioners are considered from wellknown international journals, namely PROQUEST, EMERALD, EBSCO, IEEE, ACM, JSTOR, Science Direct, etc. The research also takes into account the primary data which includes interviews and discussions with top level management and other stakeholders in the Group.

\section{SCM at JMI Group}

Thorough study and analysis of the primary and secondary data led the researchers to originate conceptual structures for JMI Group, which include a holistic view, simplified models for individual company [22] and integrated models signifying manufacturing and service process for the whole Group.

\subsection{Holistic View}

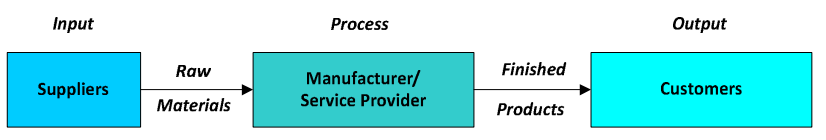

Figure 3. A Holistic View of Supply Chain of JMI Group[22]

A holistic view of Supply Chain of JMI Group in terms of input, process and output is represented in Fig. 3. Suppliers, customers, raw materials and finished products are recognized. JMI Group is processing from the raw materials to finished products as a manufacturer or service provider [22].

\subsection{Simplified Model}

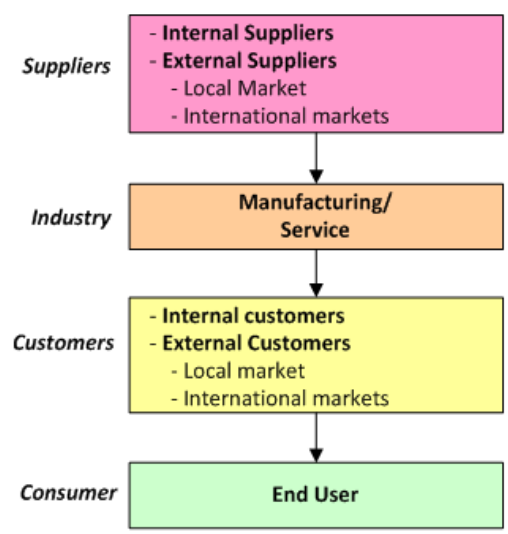

Figure 4. Simplified Model of Supply Chain of JMI Group [22]

Fig. 4 denotes a simplified model of Supply Chain of JMI Group in terms of suppliers, industry, customers and consumers. Internal Suppliers, External Suppliers (local market and international markets), Internal Customers, External Customers (local market and international markets) and End User are acknowledged. JMI Group is functioning as either manufacturer or service provider [22].

\subsection{JMI Syringes and Medical devices Ltd (Particular Model)}

Fig. 5 represents a particular model of Supply Chain of JMI Syringes \& Medical Devices in terms of suppliers, process, customers and end user.

Internal suppliers (JMI Hospital Requisite \& Manufacturing Ltd, JMI Industrial Gas Ltd, JMI Printing \& Packaging Ltd), external suppliers (local market - raw materials, packing materials, chemicals and other materials, international markets - raw materials, chemicals and other materials), internal customers (Nipro JMI Dialysis Centre Ltd, 
JMI Vaccine Ltd, Nipro JMI Pharma Ltd), external customers (local market - pharmaceutical industries, government agencies, distributors, retailers), international market (export in different countries) and patient are recognized. JMI Syringes \& Medical Devices Ltd is processing as manufacturer [22].

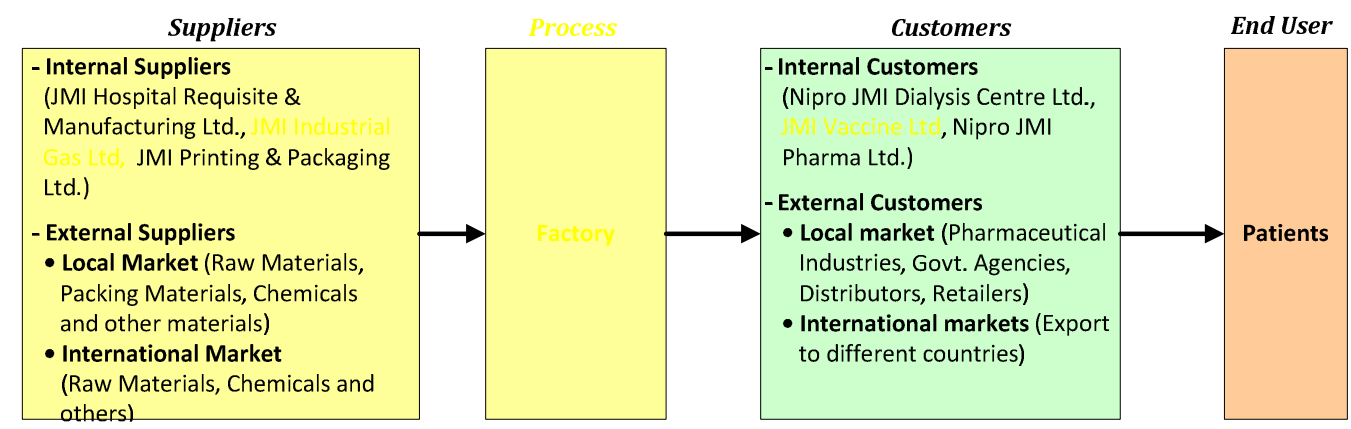

Figure 5. Particular Model of Supply Chain of JMI Syringes \& Medical devices Ltd [22]

\subsection{JMI Hospital Requisite \& Manufacturing Ltd (Particular Model)}

A particular model of Supply Chain of JMI Hospital Requisite \& Manufacturing Ltd in terms of suppliers, process, customers and end user are revealed in fig. 6. It is to be observed that Supply Chain of JMI Hospital Requisite \& Manufacturing Ltd has both types of process functions i.e. manufacturer (factory) and service provider. Internal

suppliers (JMI Printing \& Packaging Ltd), external suppliers (local market - raw materials, packing materials, chemicals and other materials, international markets - raw materials other materials), internal customers (JMI Syringes \& Medical Devices Ltd, Nipro JMI Company Ltd), external customers (local market - distributors, retailers, international markets export to different countries) and patient are acknowledged for manufacturing process [22].

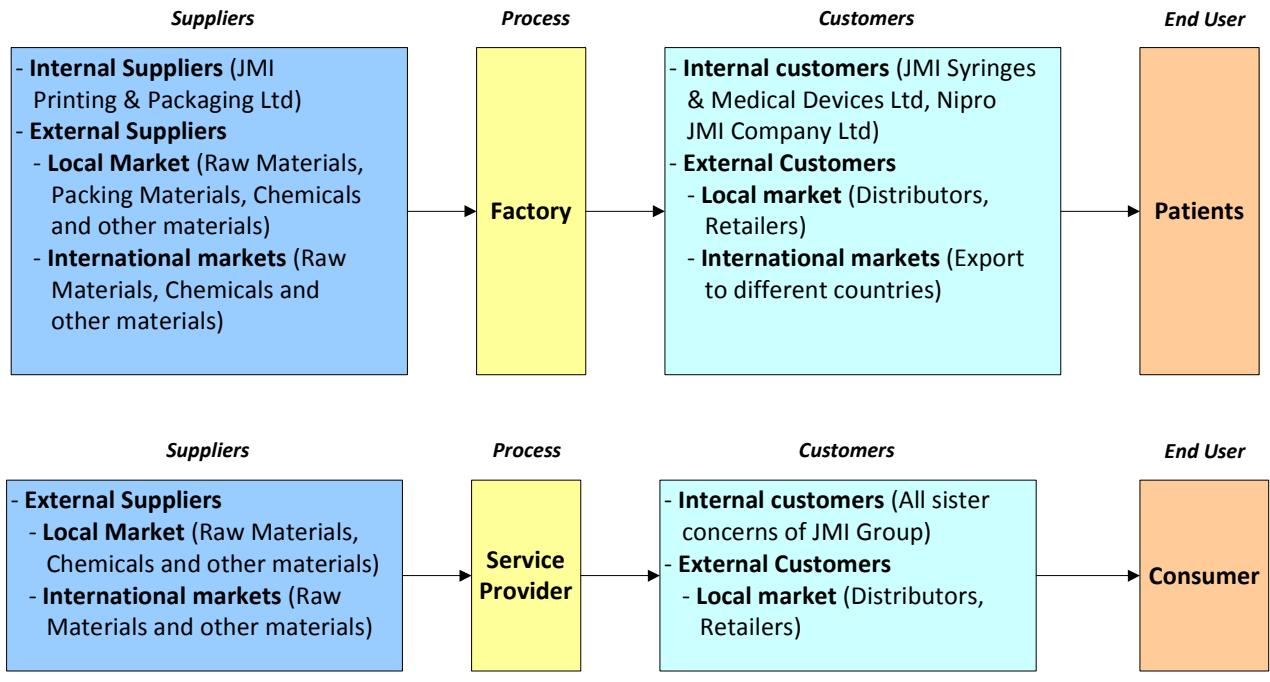

Figure 6. Particular Model of Supply Chain of JMI Hospital Requisite \& Manufacturing Ltd [22]

On the other hand, external suppliers (local market - raw materials, chemicals and other materials, international markets - raw materials and other materials), internal customers (all sister concerns of JMI Group), external customers (local market - distributors, retailers) and consumer are found as a service provider [22].

\subsection{Nipro JMI Dialysis Centre Ltd (Particular Model)}

Fig. 7 shows a particular model of supply chain of Nipro JMI Dialysis Centre Ltd in terms of suppliers, process, and customers/end user. Internal suppliers (JMI Syringes \& Medical Devices Ltd, Nipro JMI Company Ltd, Nipro JMI Pharma Ltd, and JMI Printing \& Packaging Ltd), external suppliers (local market - raw materials, chemicals and other materials, international markets - raw materials) and patients are recognized [22].

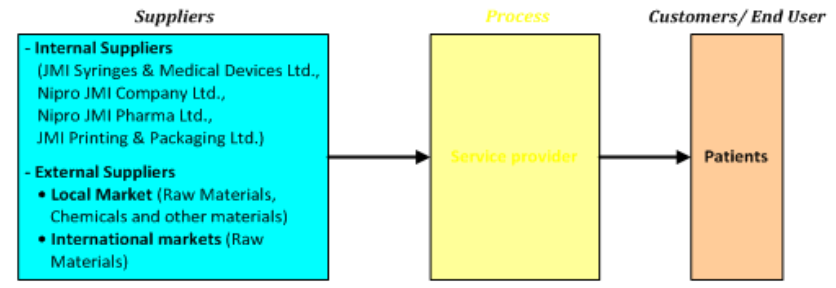

Figure 7. Particular Model of Supply Chain of Nipro JMI Dialysis Centre Ltd [22] 


\subsection{Nipro JMI Pharma Ltd (Particular Model)}

Fig. 8 represents a particular model of Supply Chain of Nipro JMI Pharma Ltd in terms of suppliers, process, customers and end user. Internal Suppliers (JMI Syringes \& Medical Devices Ltd, JMI Printing \& Packaging Ltd), External Suppliers (Local Market - Raw Materials, Packing Materials, Chemicals and other Materials, International
Markets - Raw Materials, Chemicals and other materials), Internal Customers (Nipro JMI Dialysis Centre Ltd), External Customers (Local Market - Hospitals, Distributors, and Retailers), International Markets (export in different countries) and patient are identified. Nipro JMI Pharma Ltd is processing as manufacturer.

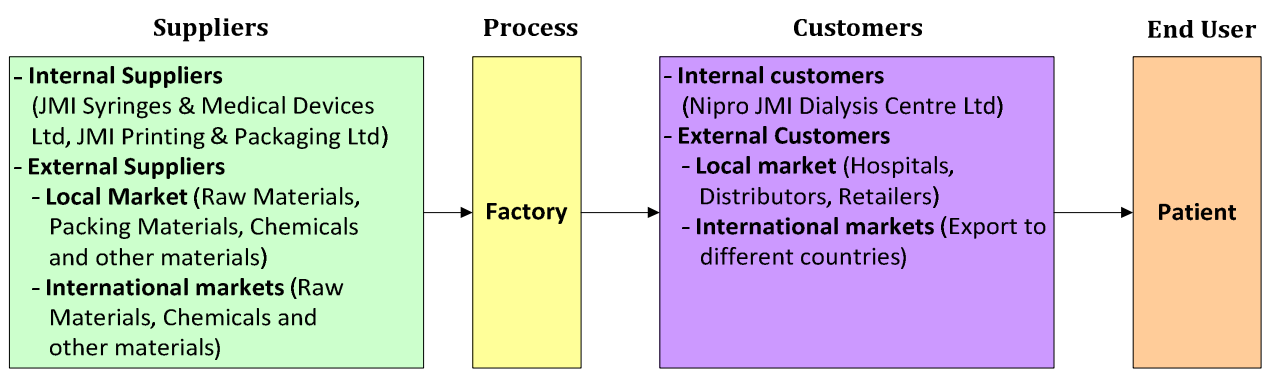

Figure 8. Particular Model of Supply Chain of Nipro JMI Pharma Ltd

\subsection{Nipro JMI Company Ltd (Particular Model)}

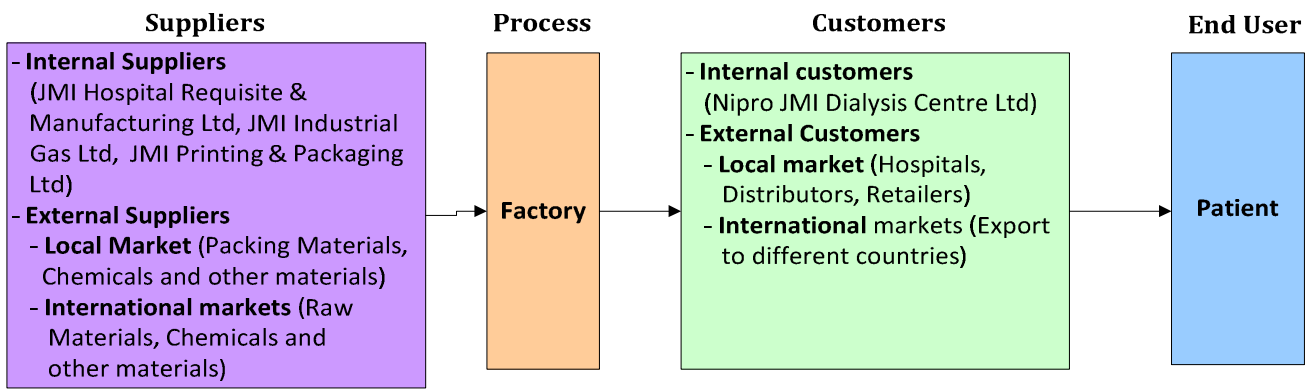

Figure 9. Particular Model of Supply Chain of Nipro JMI Company Ltd

Fig. 9 represents a particular model of Supply Chain of Nipro JMI Company Ltd in terms of suppliers, process, customers and end user. Internal Suppliers (JMI Hospital Requisite \& Manufacturing Ltd, JMI Industrial gas Ltd, JMI Printing \& Packaging Ltd), External Suppliers (Local Market - Packing Materials, Chemicals and other Materials, International Markets - Raw Materials, Packing Materials,
Chemicals and other materials), Internal Customers (Nipro JMI Dialysis Centre Ltd), External Customers (Local Market - Hospitals, Distributors, and Retailers), International Markets (export to different countries) and patient are identified. Nipro JMI Company Ltd is processing as manufacturer.

\subsection{JMI CNG Dispensing Ltd (Particular Model)}

\section{Suppliers}

Process

\begin{tabular}{|l|}
\hline - External Suppliers \\
- Padma Oil Company Ltd \\
- Local Market (Raw \\
Materials)
\end{tabular}

Figure 10. Particular Model of Supply Chain of JMI CNG Station Ltd

\section{Customers}

- Internal Customers (all sister concerns of JMI Group) companies, car owners) - External Customers (Transport

\section{End User}

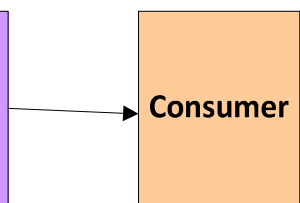

Fig. 10 represents a particular model of Supply Chain of JMI CNG Dispensing Ltd in terms of suppliers, process, customers and end user. External Suppliers (Padma Oil Company Ltd, Local Market - Raw Materials), Internal Customers (all sister concerns of JMI Group), External Customers (Transport companies and car owners) and Consumer are identified. JMI CNG Dispensing Ltd is processing as service provider.

\subsection{JMI Builders \& Constructions Ltd (Particular Model)}

Fig. 11 represents a particular model of Supply Chain of JMI Builders \& Constructions Ltd in terms of suppliers, process, customers and end user. Internal Suppliers (JMI Hollow Block Company Ltd, JMI Printing \& Packaging Ltd), 
External Suppliers (Local Market - Raw Materials and other Materials, International Markets - Raw Materials and other materials), Internal Customers (all sister concerns of JMI
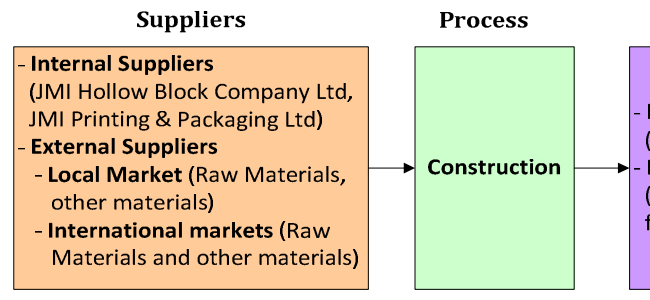

Group), External Customers (corporate houses and families) and Consumer are identified. JMI Builders \& Constructions Ltd is processing through constructing infrastructures.

Figure 11. Particular Model of Supply Chain of JMI Builders \& Constructions Ltd

\subsection{JMI Export \& Import Company Ltd (Particular Model)}

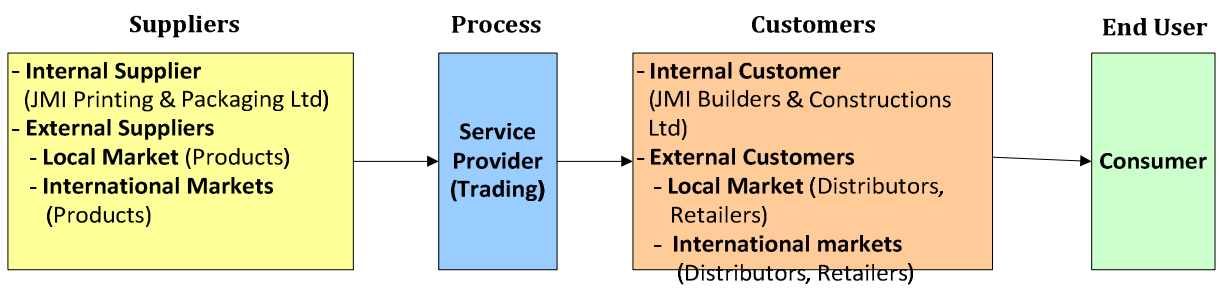

Figure 12. Particular Model of Supply Chain of JMI Export \& Import Company Ltd

Fig. 12 represents a particular model of Supply Chain of JMI Export \& Import Company Ltd in terms of suppliers, process, customers and end user. Internal Supplier (JMI Printing \& Packaging Ltd), External Suppliers (Local Market - Products, International Markets - Products), Internal Customer (JMI Builders \& Construction Ltd), External
Customers (Local Market - Distributors, Retailers, International Market - Distributors, Retailers) and Consumer are identified. JMI Export \& Import Company Ltd is processing as service provider (Trading).

\subsection{JMI Hollow Block Company Ltd (Particular Model)}

Suppliers

Process

\section{Customers}

- Internal customer

(JMI Builders \& Constructions Ltd)

- External Customers

- Local market (Industries,

Distributors, Retailers)
End User

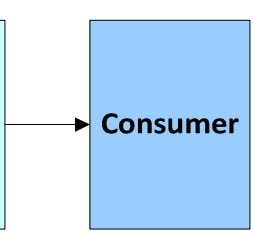

Figure 13. Particular Model of Supply Chain of JMI Hollow Block Company Ltd

Suppliers

\begin{tabular}{l}
\hline - External Suppliers \\
- Local Market (Raw Materials, \\
chemicals) \\
- International Markets (Raw \\
Materials, Chemicals)
\end{tabular}

Customers

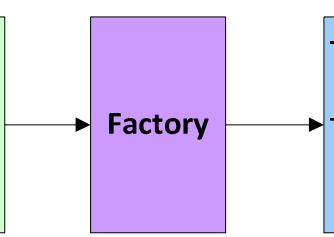

- Internal customers

(All sister concerns of JMI Group)

- External Customers

- Local market (Industries,

business houses)

Figure 14. Particular Model of Supply Chain of JMI Printing \& Packaging Industry Ltd

Fig. 13 represents a particular model of Supply Chain of JMI Hollow Block Company Ltd in terms of suppliers, process, customers and end user. Internal Suppliers (JMI Printing \& Packaging Ltd), External Suppliers (Local Market - Raw Materials and other Materials), Internal Customers (JMI Builders \& Constructions Ltd), External Customers (Industries, Distributors, Retailers) and Consumer are identified. JMI Hollow Block Company Ltd is processing as manufacturer.

\subsection{JMI Printing \& Packaging Industry Ltd (Particular Model)}

Fig. 14 represents a particular model of Supply Chain of JMI Printing \& Packaging Industry Ltd in terms of suppliers, process, customers and end user. External Suppliers (Local Market - Raw Materials and Chemicals, International Markets - Raw Materials and Chemicals), Internal 
Customers (all sister concerns of JMI Group), External Customers (Local Market - Industries, business houses) and Consumer are identified. JMI printing \& Packaging Ltd is processing as manufacturer

\subsection{JMI Industrial Gas Ltd (Particular Model)}

Fig. 15 represents a particular model of Supply Chain of JMI Industrial Gas Ltd in terms of suppliers, process, customers and end user. External Suppliers (Local Market Raw Materials and Chemicals, International Markets - Raw Materials, Packing Materials, Chemicals and other materials), Internal Customers (JMI Syringes and Medical Devices Ltd, Nipro JMI Company Ltd), External Customers (Local Market - Medical Device Industries, Hospitals, Distributors, and Retailers and patient are identified. JMI Industrial Gas is processing as manufacturer.

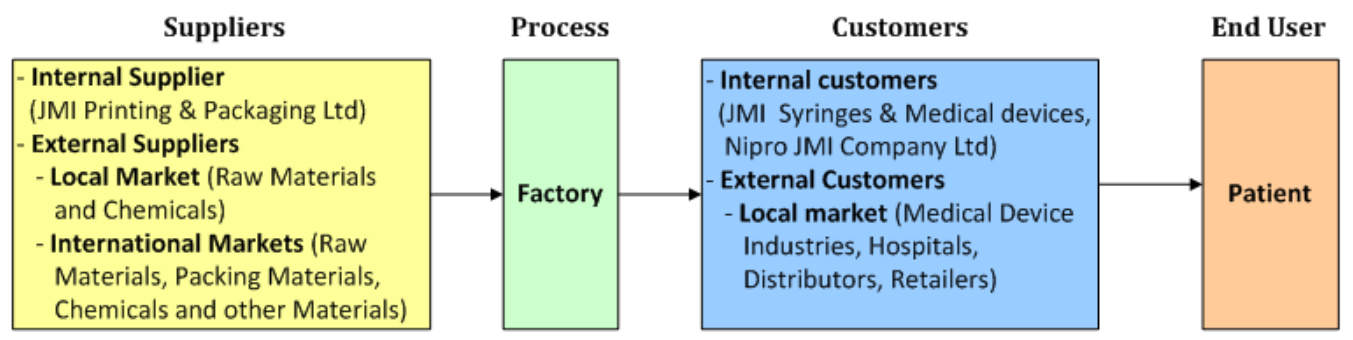

Figure 15. Particular Model of Supply Chain of JMI Industrial Gas Ltd

\subsection{JMI Vaccine Ltd (JVL)}

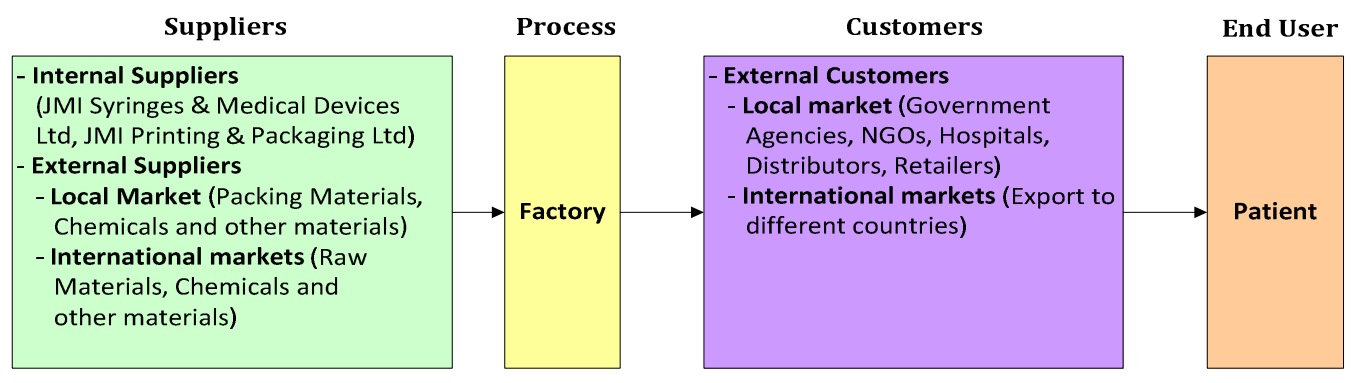

Figure 16. Particular Model of Supply Chain of JMI Vaccine Ltd

Fig. 16 represents a particular model of supply chain of JMI Vaccine Ltd in terms of suppliers, process, customers and end user. Internal Suppliers (JMI Syringes \& Medical Devices Ltd, JMI Printing \& Packaging Ltd), External Suppliers (Local Market - Packing Materials, Chemicals and other Materials, International Markets - Raw Materials, Chemicals and other materials), External Customers (Local Market - Government Agencies, NGOs, Hospitals, Distributors, and Retailers), International Markets (export in different countries) and patient are identified. Nipro JMI Vaccine Ltd is processing as manufacturer.

\subsection{Integrated Models for JMI Group Supply Chain}

It is observed that two types of processes of supply chain are involved in the subsidiaries of JMI Group, i.e. manufacturing process and service process. Basing on the types of processes, two integrated models of supply chain are designed for JMI Group. It can be comprehended that these integrated models have relationship with the particular models of all the subsidiaries of this Group (described above). These are illustrated in the subsequent paragraphs.

\subsubsection{Integrated Model for JMI Group Supply Chain - Manufacturing Process}

Fig. 17 represents the Integrated Model for JMI Group
Supply Chain - Manufacturing Process. In this model it can be envisaged that JMI printing and Packaging Ltd does not have any internal supplier (fig. 14) but all other subsidiaries are the internal customer of JPPL. Similarly for other subsidiaries it can be observed that they have one or more internal supplier/ suppliers and one or more internal customer/ customers (fig. 5 to fig.16). Left hand side of any company connected by arrow denotes as internal supplier and right hand side of the companies connected by arrows denotes internal customer in Fig. 17.

\subsubsection{Integrated Model for JMI Group Supply Chain- Service Process}

Fig. 18 represents the Integrated Model for JMI Group Supply Chain - Service Process. In this model it can be visualized that JMI Hospital Requisite Manufacturing Ltd, JMI CNG Dispensing Ltd and JMI Builders and Constructions Ltd are the internal suppliers for all other subsidiaries of this Group and all other subsidiaries are the internal customers of these concerns (fig. 5 to fig.16). These three companies are also linked to each other as indicated by the connecting arrows, denoting that each of them is performing both for other two, i.e. internal supplier and internal customer. It may be noted that though JBCL is one of the subsidiaries' that is performing as internal supplier of all 
other subsidiaries but it is shown again as the internal customer of JEICL.

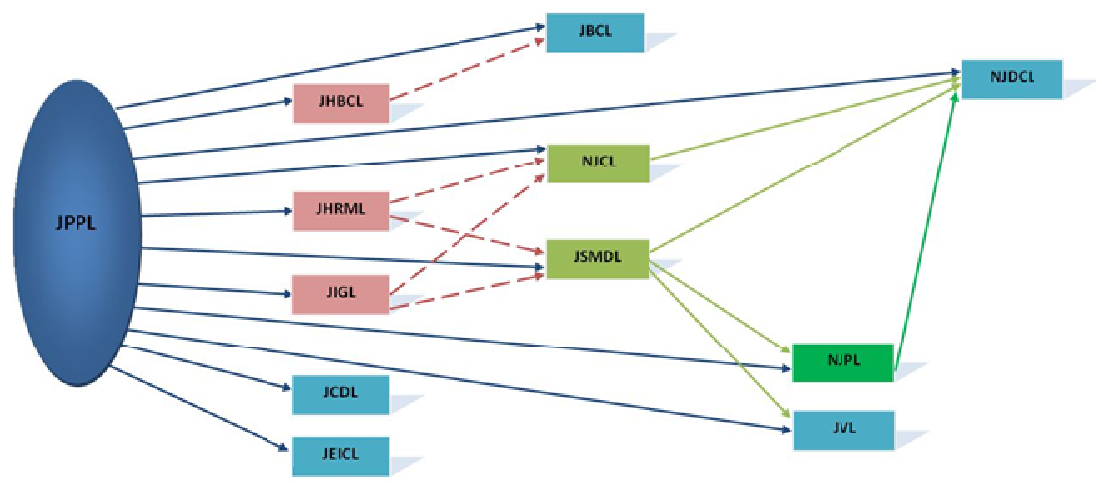

JPPL: JMI Printing and Packaging Ltd. JHBCL: JMI Hollow Block Co. Ltd. JIGL: JMI Industrial Gas Ltd. JCDL: JMI CNG Dispensing Ltd. JEICL: JMI Export Import Co Ltd. JHRML: JMI Hospital Requisites \& Manufacturing Ltd.
JBCL: JMI Builders and Constructions Ltd.

NJCL: Nipro JMI Co Ltd.

NJPL: Nipro JMI Pharma Ltd.

JVL: JMI Vaccine Ltd.

NJDCL: Nipro JMI Dialysis Center Ltd.

JSMDL: JMI Syringes and Medical Devices Ltd.

Figure 17. Represents the Integrated Model for JMI Group Supply Chain-Manufacturing Process

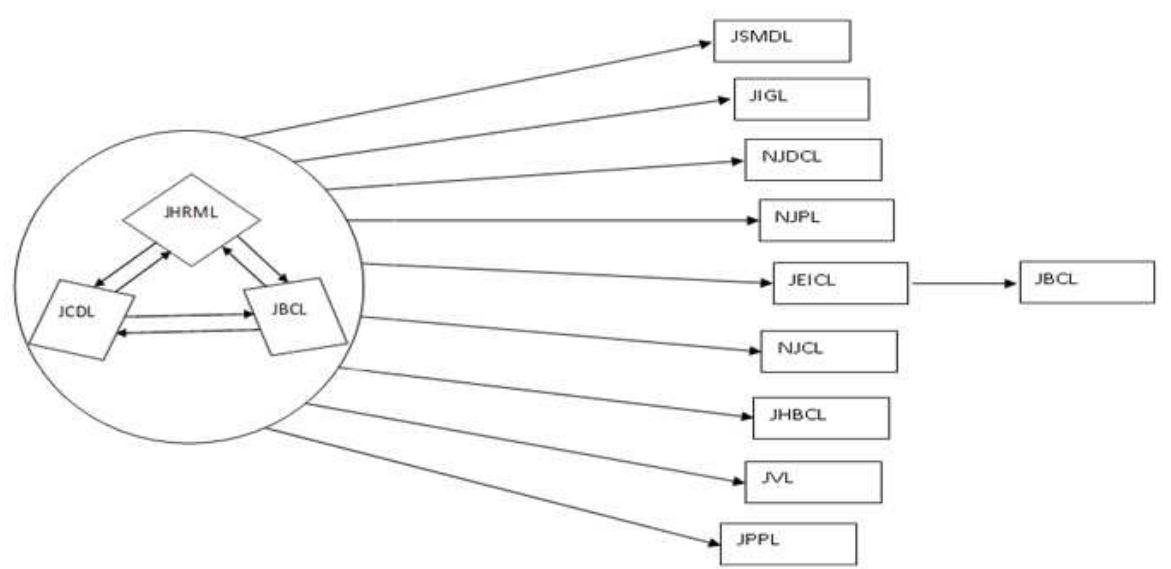

JPPL: JMI Printing and Packaging Ltd. JHBCL: JMI Hollow Block Co. Ltd. JIGL: JMI Industrial Gas Ltd. JCDL: JMI CNG Dispensing Ltd. JEICL: JMI Export Import Co Ltd. JHRML: JMI Hospital Requisites \& Manufacturing Ltd.
JBCL: JMI Builders and Constructions Ltd. NJCL: Nipro JMI Co Ltd. NJPL: Nipro JMI Pharma Ltd. JVL: JMI Vaccine Ltd. NJDCL: Nipro JMI Dialysis Center Ltd.

JSMDL: JMI Syringes and Medical Devices Ltd.

Figure 18. Represents the Integrated Model for JMI Group Supply Chain-Service Process

\section{Conclusion}

This study exemplifies various sequential procedures to design conceptual SCM model for JMI Group in order to outline different functions under SCM department. JMI Group is one of the most capable and very fast growing conglomerates in Bangladesh. A holistic view as whole, simplified models for individual companies and integrated models incorporating all the subsidiaries of JMI Group identifying manufacturing and service processes had been designed while framing conceptual structure for the supply chain of JMI Group. Holistic view can be pronounced in terms of input, process and output. Suppliers, customers, raw materials and finished products are identified. Simplified model can be described in terms of suppliers, industry, customers and consumers. Internal suppliers, external suppliers (local market and international markets), internal customers, external customers (local market and international markets) and end user are identified. This Group is processing from the raw materials to finished products as a manufacturer or service provider. Integrated models for manufacturing and service processes are displaying how all the subsidiaries of JMI Group are inter connected to each other performing as either internal supplier or internal 
customer depending on their connectivity shown by arrow and their relative positions on the diagram.

Although this study is based on case study, however, it would be rewarding for other industries of both developed and developing countries. Therefore, this paper would expose further frontiers for the potential entrepreneurs, current administrators, and academic researchers to ascertain enhanced operations of SCM in various establishments.

\section{References}

[1] Chopra, S. and Meindl, P. 'Supply Chain Management', Prentice Hall, NJ, 2001

[2] Habib, M. M., "Supply Chain Management for Academia - An Integrated Tertiary Educational Supply Chain Management (ITESCM)", LAP Lambert Academic Publishing, Germany, December 2010, ISBN 978-3-8433-8026-3

[3] Pathik, B. B. and Habib, M. M. "Application of ITESCM model for Better Supply Chain Management in Universities", International Journal of Supply Chain Management (IJSCM), ExcelingTech Publisher, UK, Vol. 1, No. 2, September 2012, ISSN: 2050-7399 (Online), 2051-3771 (Print)

[4] Christopher, M. 'Logistics and Supply Chain Management', Pitman Publishing, New York, NY, 1994

[5] Houlihan, J. B. "International Supply Chains: A New Approach,” Management Decision, Vol. 26, No. 3, 1988, pp. 13-19

[6] Horvath, Laura. "Collaboration: the key to value creation in supply chain management”, Supply Chain Management: An International Journal, Vol. 6 No. 5, 2001, pp. 205-207

[7] Baatz, E.B. "CIO100-best practices: the chain gang”, CIO, Vol.8 No.19, 1995, pp.46-52

[8] Jones, T. and Riley, D. W., "Using Inventory for Competitive Advantage through Supply Chain Management," International Journal of Physical Distribution and Materials Management, Vol. 15, No. 5, 1985, pp. 16-26

[9] Tan, K.C., Handfield, R.B. and Krause, D.R. "Enhancing firm's performance through quality and supply base management: an empirical study", International Journal of Production Research, Vol. 36 No. 10, 1998, pp.2813-37
[10] Stevenson, W.J. (2002). Operations Management, 7th ed., McGraw-Hill/Irwin, NY

[11] Habib, M. (2014) Supply Chain Management (SCM): Its Future Implications. Open Journal of Social Sciences, Vol. 2, No. 9, pp.238-246, ISSN: 2327-5952 (Print), 2327-5960 (Online), http://dx.doi.org/10.4236/jss.2014.29040

[12] Lummus, Rhonda and Robert, J. Vokurka. (1999). "Defining supply chain management: a historical perspective and practical guidelines", Industrial Management \& Data Systems", Vol.99 No.1, pp.11-17

[13] Tyndall, Gene, Christopher Gopal, Wolfgang Partsch, and John Kamauff. (1998). "Supercharging Supply Chains: New Ways to Increase Value Through Global Operational Excellence”, NY: John Wiley \& Sons

[14] Cooper, Martha, Lisa M. Ellram, John T. Gardner, and Albert M. Hanks. (1993). "Meshing Multiple Alliances," Journal of Business Logistics, Vol. 18, No. 1, pp. 67-89

[15] Monczka, Robert, Robert Trent, and Robert Handfield. (1994). Purchasing and Supply Chain Management, Cincinnati, OH: South-Western College Publishing, Chapter 8

[16] Stevens, Graham C. (1989). "Integrating the Supply Chains," International Journal of Physical Distribution and Materials Management, Vol. 8, No. 8, pp. 3-8

[17] Monczka, R. M. and Morgan, J. (1997). "What's wrong with supply chain management”, Purchasing, pp. 69-72

[18] Talluri, S., "Enhancing Supply Decisions through the Use of Efficient Marginal Cost Models", The Journal of Supply Chain Management, UK, 2002, pp. 4-10

[19] Closs, D. J. (1995). "Enhance supply chain effectiveness", Transportation \& Distribution, Vol. 36 No.4, pp.82

[20] Weil, M. (1998). “Customize the customer", Manufacturing Systems, Vol.16 No. 4, pp.54-64

[21] Crom, S. (1996). "De -fuse multi-cultural clashes", Transportation \& Distribution, July, Vol. 37 No.7, pp.84

[22] Huda, A. K. M. N., Pathik, B. B., Mohib, A. A. and Habib, M. M, "Structuring Supply Chain Model for JMI Group: A Case Study", Proceedings of the International Conference on Innovation Driven Supply Chain 2014, AIMST University, Bedong, Kedah Darul Aman, Malaysia, 26th - 28th March 2014. ISBN: 978-983-43522-2-6 